Biol. Stud. 2020: 14(2); 17-26 • DOI: https://doi.org/10.30970/sbi.1402.617

www.http://publications.Inu.edu.ua/journals/index.php/biology

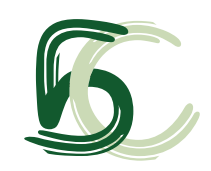

UDC 504.504+579.695

\title{
REDUCTION OF Cr(VI) COMPOUNDS BY THE IMMOBILIZED CELLS OF SULFATE-REDUCING BACTERIA DESULFOMICROBIUM SP. CrR3
}

\author{
T. B. Peretyatko ${ }^{(1 *}$, K. V. Sholiak ${ }^{(2)}$, \\ A. A. Halushka@1, I. M. Stakhera ${ }^{\circledR 3}$, H. V. Tsehelyk ${ }^{3}$ \\ ${ }^{1}$ Ivan Franko National University of Lviv, 4, Hrushevskyi St., Lviv 79005, Ukraine \\ ${ }^{2}$ General education school of I-III level Dubrynychi village of Transcarpathian region \\ 73, Tsentralna St., Dubrynychi 89210, Ukraine \\ ${ }^{3}$ HECI LRC "Andrei Krupynskyi Lviv Medical Academy", 70, P. Doroshenko St., Lviv 79000, Ukraine \\ ${ }^{*}$ Corresponding author: e-mail: taras.peretyatko@Inu.edu.ua
}

Peretyatko T.B., Sholiak K.V., Halushka A.A., Stakhera I.M., Tsehelyk H.V. Reduction of Cr(VI) compounds by the immobilized cells of sulfate-reducing bacteria Desulfomicrobium sp. CrR3. Studia Biologica, 2020: 14(2); 17-26 • DOI: https://doi.org/10.30970/sbi.1402.617

Immobilization of microorganisms is an effective method of intensification of wastewater purification form chromate-containing compounds. This paper presents a method of sulfate-reducing bacteria immobilization in agar developed in order to determine the effectiveness of water purification from toxic hexavalent chromium compounds. Dependence of the influence of different factors on the reduction of hexavalent chromium compounds by immobilized cells of sulfate-reducing bacteria Desulfomicrobium sp. CrR3 has been studied. Both free and agar-immobilized Desulfomicrobium sp. CrR3 cells almost completely reduced $\mathrm{Cr}(\mathrm{VI})$ at the initial concentration of $1 \mathrm{mM}$. Immobilized cells reduced over $90 \%$ of $\mathrm{Cr}(\mathrm{VI})$ in 4 days, and non-immobilized ones - in 6 days. $\mathrm{Cr}$ (III) content increased with the decrease of hexavalent chromium concentration. A possibility of multiple usage of agar-immobilized Desulfomicrobium sp. CrR3 cells for the purification of the model solution from $\mathrm{Cr}(\mathrm{VI})$ at the concentration of $0.5 \mathrm{mM}$ and $1 \mathrm{mM}$ during $60 \mathrm{~h}$ was confirmed. After three-time usage of the immobilized cells $(1 \mathrm{~g} / \mathrm{L})$, effectiveness of $\mathrm{Cr}(\mathrm{VI})$ reduction is $68 \%$ at their initial concentration of $0.5 \mathrm{mM}$ and $50 \%$ - at $1 \mathrm{mM}$; at cells concentration $3 \mathrm{~g} / \mathrm{L}-87 \%$ and $77 \% ; 5 \mathrm{~g} / \mathrm{L}-94 \%$ and $92 \%$, and at cells concentration $8 \mathrm{~g} / \mathrm{L}-98 \%$ and $96 \%$, respectively. As a result of the regression analysis of the influence of different factors on the purification of the model solution from $\mathrm{Cr}(\mathrm{VI})$ by agar-immobilized Desulfomicrobium sp. CrR3 cells a reliable dependence of the studied parameter change on time, initial content of hexavalent chromium and cells concentration was found. Determination indices have been calculated and the

() 2020 T. B. Peretyatko et al.; Published by the Ivan Franko National University of Lviv on behalf of Біологічні Студії / Studia Biologica. This is an Open Access article distributed under the terms of the Creative Commons Attribution License (http://www.budapestopenaccessinitiative.org/ and Creative Commons Attribution 4.0 License), which permits unrestricted reuse, distribution, and reproduction in any medium, provided the original work is properly cited.

ISSN 1996-4536 (print) • ISSN 2311-0783 (on-line) • Біологічні Студії / Studia Biologica • 2020 • Том 14/№2 • C. 17-26 
equation of the dependence of change of hexavalent chromium concentration per unit of time on the three analysed factors has been derived. Immobilization of Desulfomicrobium sp. CrR3 cells is the promising way of water purification from hexavalent chromium compounds. Effectiveness and duration of the process of water purification from $\mathrm{Cr}(\mathrm{VI})$ by the immobilized Desulfomicrobium sp. CrR3 bacteria depend on the initial hexavalent chromium content and cell concentration.

Keywords: $\mathrm{Cr}(\mathrm{VI})$, purification, immobilized cells, sulfate-reducing bacteria, regression analysis

\section{INTRODUCTION}

Immobilized bacterial cells are increasingly used to purify the environment from both organic and inorganic pollutants. Activated charcoal, sand, porous glass, yellow saponite, wood chips, cotton fibers, corncobs, sunflower seed shells, etc. are the carriers for immobilization [1, 3, 16]. Incorporation of cells into different by structure natural (caraginane, agar, collagen, pectines) and synthetic (chitosan, silicate foam, polyurethane, polyacrylamide gel, photosensitive polymers) polymers is equally widespread [1, 17]. Biodegradable organic compounds (based on vinyl [2], alginates [1], and cotton fibers [3]) are used most often.

Compared to the traditional methods of biological purification of wastewater in aerated lagoons, immobilized microbiota has a number of advantages. First, such an "immobilized catalyzer" of the purification process is easy to remove from the reaction medium, which enables termination of the process at the right moment, while removal of active sludge from an aerated lagoon involves a long process of sedimentation and centrifugation. Besides, the carrier is suitable for multiple usage; purified water is not contaminated by microbial cells, so a secondary settler is not needed. Secondly, using the immobilized active sludge makes it possible to purify wastewater continuously and regulate the purification process by changing the flow velocity. Thirdly, immobilization of microbial biomass can increase the catalytic activity of enzymes [16].

Sulfate-reducing bacteria reduce sulfur oxoanions and oxidize organic compounds in anaerobic conditions in the process of sulfate respiration $[5,10]$. Previous studies show that as electron acceptors they can also utilize nitrate ions, hexavalent chromium compounds and some heavy metal ions with variable valency $[7,13,15]$.

In this study, we made an attempt to immobilize sulfate-reducing bacteria in order to use them for water purification from toxic compounds of hexavalent chromium.

\section{MATERIALS AND METHODS}

Chromate-resistant sulfate-reducing bacteria Desulfomicrobium sp. CrR3, isolated from the wastewater of Lviv purification system, were used for this research [11].

Bacteria were grown in Postgate $C$ medium [8] with potassium dichromate $(1 \mathrm{mM}$ of chromium) at $30^{\circ} \mathrm{C}$ in $25 \mathrm{~mL}$ tubes. The choice of such a concentration of chromium was determined by the results of our previous study [12], according to which further increase of chromium content in the medium leads to the inhibition of bacterial growth. Water solution of potassium dichromate was added after sterilization. To achieve anaerobic conditions tubes were fully filled with the medium and stoppered with rubber corks. To confirm the anaerobic conditions, Anaerlndicator (bioMeriux, France) - an indicator of anaerobic conditions was used.

ISSN 1996-4536 (print) • ISSN 2311-0783 (on-line) • Біологічні Студії / Studia Biologica • 2020 • Том 14/№2 • С. 17-26 
Biomass was measured turbidimetrically using the photoelectrocolorymeter KFK-3 $(\lambda=340 \mathrm{~nm}$, cuvette $3 \mathrm{~mm})$. Chromate content was measured spectrophotometrically $(\lambda=540 \mathrm{~nm}$, cuvette $10 \mathrm{~mm}$ ) by biphenyl carbaside method [6]. Chromasurol $\mathrm{S}$ ( $\lambda=590 \mathrm{~nm}$, cuvette $10 \mathrm{~mm}$ ) was used to measure $\mathrm{Cr}$ (III) content [4].

To immobilize cells of sulfate-reducing bacteria on the synthetic carrier "VIIA", we grew them in the tube with synthetic fibres. After 14 days, "VIIA" were added to the model solution. To obtain Desulfomicrobium sp. CrR3 cells immobilized in agar, the grown bacteria were centrifuged at $6000 \mathrm{~g}$ for $30 \mathrm{~min}$ at $4{ }^{\circ} \mathrm{C}$. The cells were washed twice with the isotonic solution of sodium chloride and added to $2 \%$ agar solution cooled to $40 \ldots 45^{\circ} \mathrm{C}$. The agarized solution with the cells was poured into Petri plates to form a uniform layer. After solidification, the agar was cut into $7-8 \times 7-8 \times 7-8 \mathrm{~mm}$ cubes and added to the model solution of potassium dichromate containing $\mathrm{Cr}(\mathrm{VI})$ with $\mathrm{pH}$ adjusted to 7 .

Statistical analysis was performed in $\mathrm{R}$ medium (3.6.3) in RStudio envelope (1.2.5033) using ggplot2 library [9]. Method of multiple linear regression with different variable combinations in linear model was used to determine the significance of the dependence of chromium concentration on such parameters as initial chromium concentration, time of measuring after the addition of chromium and concentration of cells.

\section{RESULTS AND DISCUSSION}

This study was focuses on a possibility to immobilize sulfate-reducing bacteria Desulfomicrobium sp. CrR3 on the synthetic carrier "VIIA", which is considered to be promising and readily available [14], and in agar. Effective growth of sulfate-reducing bacteria Desulfomicrobium sp. CrR3 in the $\mathrm{Cr}(\mathrm{VI})$ containing medium without sulfates and other terminal electron acceptors was reported previously [12]. After 14 days of Desulfomicrobium sp. CrR3 bacteria cultivation in Postgate C medium with "VIIA" carriers, bacterial biomass accumulated, but no immobilization occured. Bacterial biomass was equal in both culture liquids, with and without the synthetic fibres. Sedimentation of FeS, which stained the carrier in black colour, was observed in Postgate $\mathrm{C}$ medium with ferrous sulfate.

The synthetic carrier was substituted for agar, as immobilization on the synthetic carrier "VIIA" was not successful. The pattern of chromate ions utilization by the sulfatereducing bacteria Desulfomicrobium sp. CrR3 immobilized in agar proved to be similar to the pattern of $\mathrm{Cr}(\mathrm{VI})$ utilization by non-immobilized cells. The cells were immobilized in agar and their ability to reduce chromate ions was studied. We found that both immobilized and non-immobilized cells almost completely reduced $\mathrm{Cr}(\mathrm{VI})$ at the initial concentration of $1 \mathrm{mM}$ (Fig. 1). The immobilized Desulfomicrobium sp. CrR3 cells reduced over $90 \%$ of $\mathrm{Cr}(\mathrm{VI})$ within 4 days, and the free ones - within 6 days. $\mathrm{Cr}(\mathrm{III})$ content increased with the decrease of chromate ions concentration. The concentration of chromate ions did not change in the control sample (without cells) (Fig. 1A).

Fig. 2 shows positive correlation between the rate of $\mathrm{Cr}(\mathrm{VI})$ utilization and the amount of immobilized cells. Multiple uses of immobilized sulfate-reducing bacteria cells for the purification of a medium from $\mathrm{Cr}(\mathrm{VI})$ are possible. $\mathrm{Cr}(\mathrm{VI})$ content in the model solution decreased from $0.5 \mathrm{mM}$ to $0.26 \mathrm{mM}$ in 17 hours after the addition of $1 \mathrm{~g} / \mathrm{L}$ of Desulfomicrobium sp. CrR3 cells immobilized in agar. After the second addition of $0.5 \mathrm{mM}$ of $\mathrm{Cr}(\mathrm{VI})$, bacteria reduced $0.17 \mathrm{mM}$ in $17 \mathrm{~h}$. With the next addition of $0.5 \mathrm{mM}$ of $\mathrm{Cr}(\mathrm{VI})$ bacteria utilized only $0.06 \mathrm{mM}$ of $\mathrm{Cr}(\mathrm{VI})$ (Fig. 2A).

ISSN 1996-4536 (print) • ISSN 2311-0783 (on-line) • Біологічні Студії / Studia Biologica • 2020 • Том 14/№2 • C. 17-26 

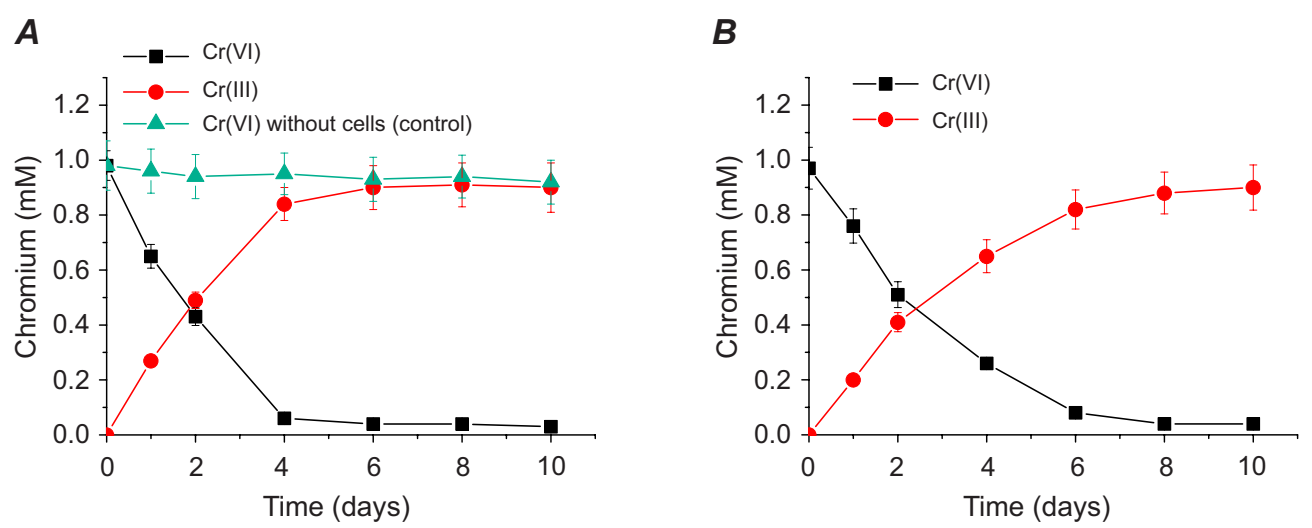

Fig. 1. Reduction of $\mathrm{Cr}(\mathrm{VI})$ by agar-immobilized $(\boldsymbol{A})$ and free $(\boldsymbol{B})$ Desulfomicrobium sp. CrR3 cells. Initial concentration of chromate ions $-1 \mathrm{mM}$; of cells $-0.1 \mathrm{~g} / \mathrm{L}$

Рис. 1. Відновлення $\mathrm{Cr}(\mathrm{VI})$ іммобілізованими в агар $(\boldsymbol{A})$ та неіммобілізованими (B) клітинами Desulfomicrobium sp. CrR3. Вихідна концентрація хромат-йонів - 1 мМ, клітин - 0,1 г/л
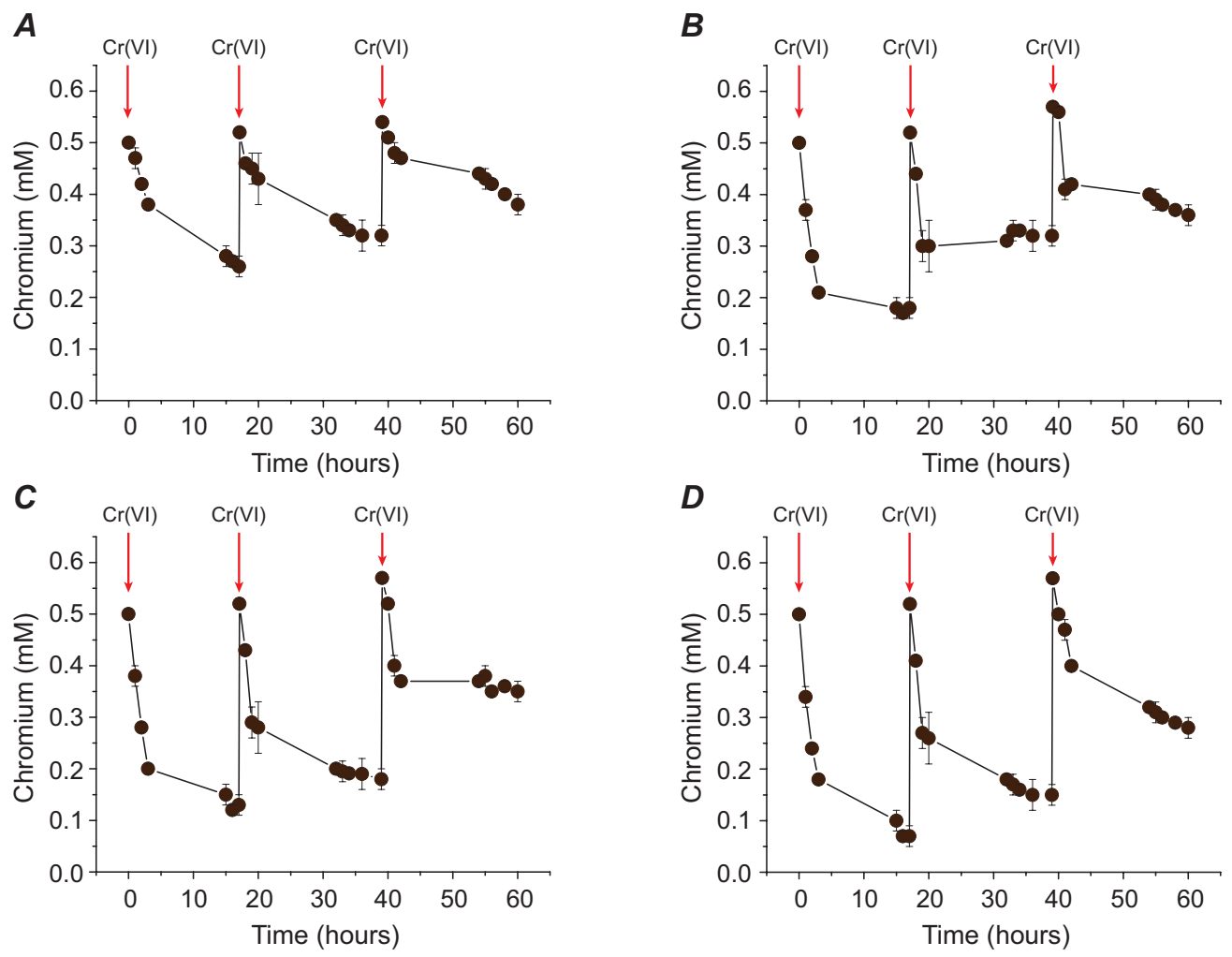

Fig. 2. Utilization of $\mathrm{Cr}(\mathrm{VI})(0.5 \mathrm{MM})$ by the agar-immobilized cells of Desulfomicrobium $\mathrm{sp}$. CrR3 bacteria at different concentration $(\boldsymbol{A}-1 \mathrm{~g} / \mathrm{L} ; \boldsymbol{B}-3 \mathrm{~g} / \mathrm{L} ; \boldsymbol{C}-5 \mathrm{~g} / \mathrm{L} ; \boldsymbol{D}-8 \mathrm{~g} / \mathrm{L})$ during $60 \mathrm{~h}$. Arrows indicate the addition of potassium dichromate into the model solution

Рис. 2. Використання $\mathrm{Cr}(\mathrm{VI})(0,5 \mathrm{mM})$ іммобілізованими в агар клітинами бактерій Desulfomicrobium sp. CrR3 за різних концентрацій $(\boldsymbol{A}-1$ г/л; $\boldsymbol{B}-3$ г/л; $\boldsymbol{C}-5$ г/л; $\boldsymbol{D}-8$ г/л) упродовж 60 год. Стрілками показано внесення калій біхромату в модельний розчин 
3 hours after the addition of $3 \mathrm{~g} / \mathrm{L}$ of agar-immobilized cells into the model solution, which contained $0.5 \mathrm{mM}$ of $\mathrm{Cr}(\mathrm{VI})$, the utilization of $0.3 \mathrm{mM}$ of $\mathrm{Cr}(\mathrm{VI})$. $\mathrm{Cr}(\mathrm{VI})$ concentration was $0.17 \mathrm{mM}$ after $17 \mathrm{~h}$ was observed. Repeated addition of $0.5 \mathrm{mM}$ of $\mathrm{Cr}(\mathrm{VI})$ resulted in the two-fold decrease of $\mathrm{Cr}(\mathrm{VI})$ utilization by bacterial cells. With the next addition of $0.5 \mathrm{mM}$ of $\mathrm{Cr}(\mathrm{VI})$ bacteria utilized only $0.15 \mathrm{mM}$ of $\mathrm{Cr}(\mathrm{VI})$ (Fig. $2 \boldsymbol{B}$ ).

The increase in concentration of the added cells to $5 \mathrm{~g} / \mathrm{L}$ accelerates the process of $\mathrm{Cr}(\mathrm{VI})$ reduction. $\mathrm{Cr}(\mathrm{VI})$ concentration in the medium reached $0.11 \mathrm{mM}$ after $17 \mathrm{~h}$. We observed an insignificant deceleration of $\mathrm{Cr}(\mathrm{VI})$ reduction in the case of a repeated addition of $0.5 \mathrm{mM}$. $\mathrm{Cr}(\mathrm{VI})$ concentration was $0.19 \mathrm{mM}$ after $34 \mathrm{~h}$. With the next addition of $0.5 \mathrm{mM}$ of $\mathrm{Cr}(\mathrm{VI})$, its utilization decelerated (Fig. $2 \mathrm{C}) .0 .06 \mathrm{mM}$ of $\mathrm{Cr}(\mathrm{VI})$ was found in the medium $17 \mathrm{~h}$ after the addition of $8 \mathrm{~g} / \mathrm{L}$ of agar-immobilized cells into the model solution with $\mathrm{Cr}(\mathrm{VI})$ concentration of $0.5 \mathrm{mM}$. Its concentration was $0.16 \mathrm{mM}$ in $17 \mathrm{~h}$ (on the 34th hour) after the repeated addition of $0.5 \mathrm{mM}$ of $\mathrm{Cr}(\mathrm{VI})$ (Fig. 2D).

A two-fold increase in the initial $\mathrm{Cr}(\mathrm{VI})$ concentration in the model solution results in different extent of its reduction by the agar-immobilized Desulfomicrobium sp. CrR3 cells depending on their concentration (Fig. 3).
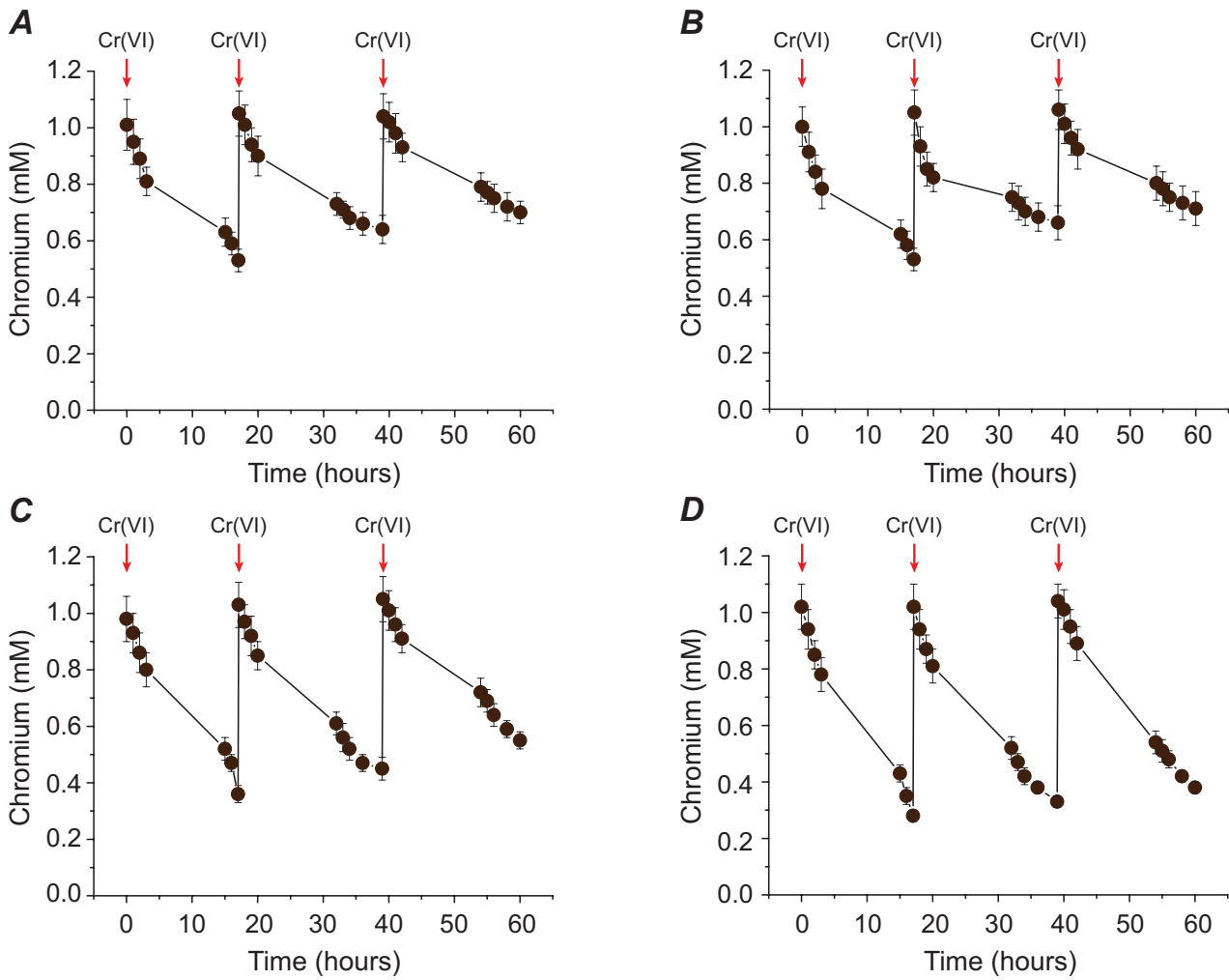

Fig. 3. Utilization of $\mathrm{Cr}(\mathrm{VI})(1 \mathrm{mM})$ by agar-immobilized cells of Desulfomicrobium sp. CrR3 bacteria at different concentrations $(\boldsymbol{A}-1 \mathrm{~g} / \mathrm{L} ; \boldsymbol{B}-3 \mathrm{~g} / \mathrm{L} ; \boldsymbol{C}-5 \mathrm{~g} / \mathrm{L}, \boldsymbol{D}-8 \mathrm{~g} / \mathrm{L})$ during $60 \mathrm{~h}$. Arrows indicate the addition of potassium dichromate into the model solution

Рис. 3. Використання $\mathrm{Cr}(\mathrm{VI})$ (1 мM) іммобілізованими в агар клітинами бактерій Desulfomicrobium sp. CrR3 за різних концентрацій клітин $(\boldsymbol{A}-1$ г/л; $\boldsymbol{B}-3$ г/л; $\boldsymbol{C}-5$ г/л; $\boldsymbol{D}-8$ г/л) упродовж 60 год. Стрілками показано внесення калій біхромату в модельний розчин 
$\mathrm{Cr}(\mathrm{VI})$ content in the model solution was decreased from 1.0 to $0.56 \mathrm{mM}$ within 17 hours after the addition of $1 \mathrm{~g} / \mathrm{L}$ of Desulfomicrobium sp. CrR3 cells immobilized in agar. After the repeated addition of $1.0 \mathrm{mM}$ of $\mathrm{Cr}(\mathrm{VI})$, bacteria reduced $0.32 \mathrm{mM}$ in $17 \mathrm{~h}$. With the next addition of $1.0 \mathrm{mM}$ of $\mathrm{Cr}(\mathrm{VI})$, bacteria utilized only $0.27 \mathrm{mM}$ of $\mathrm{Cr}(\mathrm{VI})$ (Fig. 3A).

After the addition of $3 \mathrm{~g} / \mathrm{L}$ of agar-immobilized cells into the model solution, which contained $1 \mathrm{mM}$ of $\mathrm{Cr}(\mathrm{VI})$, the utilization of $0.23 \mathrm{mM}$ of $\mathrm{Cr}(\mathrm{VI})$ after $3 \mathrm{~h}$ was observed. $\mathrm{Cr}(\mathrm{VI})$ concentration was $0.53 \mathrm{mM}$ after 17 hours. A repeated addition of $1 \mathrm{mM}$ of $\mathrm{Cr}(\mathrm{VI})$ resulted in the 1.6-fold deceleration of $\mathrm{CrO}_{4}{ }^{2-}$ utilization by cells. With the next addition of $1 \mathrm{mM}$ of $\mathrm{Cr}(\mathrm{VI})$ bacteria utilized only $0.29 \mathrm{mM}$ of $\mathrm{Cr}(\mathrm{VI})$ (Fig. 3B).

The increase of cell concentration to $5 \mathrm{~g} / \mathrm{L}$ accelerates the process of $\mathrm{Cr}(\mathrm{VI})$ reduction. $\mathrm{Cr}(\mathrm{VI})$ concentration reached $0.36 \mathrm{mM}$ after $17 \mathrm{~h}$. Its utilization decelerated in the case of a repeated addition of $1 \mathrm{mM}$ of $\mathrm{Cr}(\mathrm{VI})$. After $34 \mathrm{~h}, \mathrm{Cr}(\mathrm{VI})$ concentration was $0.52 \mathrm{mM}$. With the next addition of $1 \mathrm{mM}$ of $\mathrm{Cr}(\mathrm{VI})$, its utilization decelerated (Fig. $3 \mathrm{C}$ ).

After the addition of $8 \mathrm{~g} / \mathrm{L}$ of agar-immobilized cells into the model solution with $1 \mathrm{mM}$ of $\mathrm{Cr}(\mathrm{VI}) 0.28 \mathrm{mM}$ of $\mathrm{Cr}(\mathrm{VI})$ was found in the medium $17 \mathrm{~h} .17 \mathrm{~h}$ after the repeated addition of $1 \mathrm{mM}$ of $\mathrm{Cr}(\mathrm{VI})$ (in 34 hours), its concentration was $0.42 \mathrm{mM}$. With the next addition of $1 \mathrm{mM}$, utilization of $\mathrm{Cr}(\mathrm{VI})$ decelerated (Fig. 3D).

Thus, it is not only the concentration of cells, but also $\mathrm{Cr}(\mathrm{VI})$ concentration that influences the reduction of chromate ions by the immobilized Desulfomicrobium sp. CrR3 cells. After a three-time use of the immobilized Desulfomicrobium sp. CrR3 cells (1g/L), the effectiveness of chromate ions reduction is $68 \%$ at their initial concentration of $0.5 \mathrm{mM}$ and $50 \%$ - at $1 \mathrm{mM}$; at cells concentration of $3 \mathrm{~g} / \mathrm{L}-87 \%$ and $77 \% ; 5 \mathrm{~g} / \mathrm{L}-94 \%$ and $92 \%$, and at cells concentration of $8 \mathrm{~g} / \mathrm{L}-98 \%$ and $96 \%$, respectively (see Table).

Effectiveness of cromate ions reduction by immobilized Desulfomicrobium sp. CrR3 cells

Ефективність відновлення хромат-йонів іммобілізованими клітинами Desulfomicrobium sp. CrR3

\begin{tabular}{|c|c|c|c|c|}
\hline \multirow{3}{*}{ Chromate ions concentration (mM) } & \multicolumn{4}{|c|}{ Concentration of cells $(\mathrm{g} / \mathrm{L})$} \\
\hline & 1 & 3 & 5 & 8 \\
\hline & \multicolumn{4}{|c|}{ Effectiveness of reduction (\%) } \\
\hline 0.5 & 68 & 87 & 94 & 98 \\
\hline 1.0 & 50 & 77 & 92 & 96 \\
\hline
\end{tabular}

Thus, agar-immobilized cells of sulfate-reducing bacteria Desulfomicrobium sp. CrR3 are capable of full detoxification of $0.5 \mathrm{mM}$ of $\mathrm{Cr}(\mathrm{VI})$ in $17 \mathrm{~h}$. The increase of cells concentration accelerates the process of chromate utilization in the model solution. Desulfomicrobium sp. CrR3 bacteria have a potential for anaerobic purification of wastewater from hexavalent chromium compounds.

The study demonstrated that Desulfomicrobium sp. CrR3 cells immobilized in agar have an ability to reduce $\mathrm{Cr}(\mathrm{VI})$ at the concentration of $0.5 \mathrm{mM}$ in the model solution. The dependence of the concentration of hexavalent chromium on time (in hours) is described by the equation

$$
[\mathrm{Cr}]=0.429-0.009 \cdot t \text {, }
$$

where $[\mathrm{Cr}]$ - concentration of hexavalent chromium, mM; $t$ - time after the moment of $\mathrm{Cr}(\mathrm{VI})$ addition to the medium, hours.

ISSN 1996-4536 (print) • ISSN 2311-0783 (on-line) • Біологічні Студії / Studia Biologica • 2020 • Том 14/№2 • С. 17-26 
The dependence of chromium concentration on time is significant $(p<0.001)$, but the determination coefficients that indicate the part of variation of the dependent variable, which can be explained by the variation of predictros, are low in this model $\left(R^{2}=0.3234, R^{2}\right.$ adj $\left.=0.320\right)$. It can be seen from equation 1 that $\mathrm{Cr}(\mathrm{VI})$ concentration changes by $0.009 \mathrm{mmol}$ per hour.

At the initial $\mathrm{Cr}(\mathrm{VI})$ concentration of $1 \mathrm{mM}$ in the model solution, the dependence of hexavalent chromium concentration on time is described by the equation

$$
[\mathrm{Cr}]=0.971-0.022 \cdot t
$$

where $[\mathrm{Cr}]$ - concentration of hexavalent chromium, $\mathrm{mM} ; t$ - time after the moment of $\mathrm{Cr}(\mathrm{VI})$ addition to the medium, hours.

The dependence of chromium concentration on time is significant $(p<0.001)$ and the determination coefficients are high $\left(R^{2}=0.6873, R^{2}\right.$ adj $\left.=0.6857\right) . \mathrm{Cr}(\mathrm{VI})$ concentration decreases by $0.022 \mathrm{mmol}$ per hour (equation 2 ).

According to the regression analysis, the changes in $\mathrm{Cr}(\mathrm{VI})$ concentration when using agar-immobilized Desulfomicrobium sp. CrR3 cells conform with the interpretation of the visualization presented at Fig. 4.

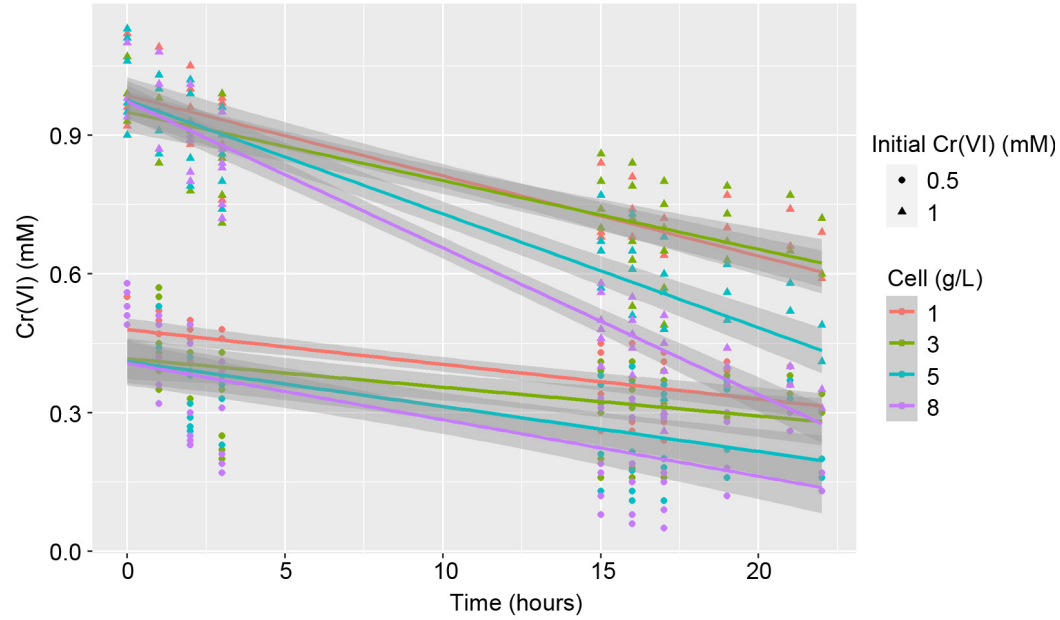

Fig. 4. Changes in $\mathrm{Cr}(\mathrm{VI})$ concentration by agar-immobilized Desulfomicrobium sp. CrR3 cells taking into account the factors of time and initial chromium content during 23 hours

Рис. 4. Зміни концентрації $\mathrm{Cr}(\mathrm{VI})$ іммобілізованими в агар клітинами Desulfomicrobium sp. CrR3 з урахуванням чинника часу і початкового вмісту хрому протягом 23 год

The multiple linear regression, performed for the dependent index - chromium concentration, and the independent indeces (predictors) - time and initial chromium concentration, shows that the change of $\mathrm{Cr}(\mathrm{VI})$ concentration is described by the equation

$[\mathrm{Cr}]=-0.114+0.004 \cdot t+1.085 \cdot\left[\mathrm{Cr}_{0}\right]-0.026 \cdot t \cdot\left[\mathrm{Cr}_{0}\right]$

where $\left[\mathrm{Cr}_{0}\right]$ - initial concentration of hexavalent chromium, $\mathrm{mM}$.

In this case, the $p$-level of significance of dependence of $\mathrm{Cr}(\mathrm{VI})$ concentration on time is low $(p=0.0544)$, and the coefficient of this predictor is positive, which indicates that only time in this model is not a significant parameter. However, the $p$-level of significance of dependence of hexavalent chromium concentration on the initial $\mathrm{Cr}(\mathrm{VI})$ concentration is notable $(p<0.001)$ in the same manner as for the interaction/combination of these factors (the extent of expression of measuring time factor significantly depends on

ISSN 1996-4536 (print) • ISSN 2311-0783 (on-line) • Біологічні Студії / Studia Biologica • 2020 • Том 14/№2 • C. 17-26 
the gradation of the initial chromium concentration, $p<0.001)$. Determination coefficients for such a model indicate that a significant part of the chromium concentration variability is described by the variability of these two parameters $\left(R^{2}=0.829, R^{2}{ }_{\text {adj }}=0.827\right)$.

Thus, the influence of the factor of time depends significantly on other parameters, particularly, the initial concentration of $\mathrm{Cr}(\mathrm{VI})$, which by itself is a significant predictor.

The multiple linear regression, performed for the dependent index of chromium concentration and for the independent indices of time, Desulfomicrobium sp. CrR3 cells concentration and the initial $\mathrm{Cr}(\mathrm{VI})$ concentration, shows that the change of hexavalent chromium concentration is described by the equation

$[\mathrm{Cr}]=-0.037+1.010 \cdot\left[\mathrm{Cr}_{0}\right]-0.018 \cdot[\mathrm{C}]-0.013 \cdot t \cdot[\mathrm{C}]-0.003 \cdot t \cdot\left[\mathrm{Cr}_{0}\right] \cdot[\mathrm{C}]$, where $[\mathrm{C}]-$ concentration of cells, $\mathrm{g} / \mathrm{L}$.

The most significant predictor is the initial $\mathrm{Cr}(\mathrm{VI})$ concentration $(p<0.001)$ and an aggregate of all three factors (expression of time as a factor depends on the initial chromium concentration factor gradation and cells concentration, $p \approx 0.001$ ). Time in relation to the gradation of initial chromium concentration $(p=0.003)$ and concentration of cells $(p=0.046)$ are significant factors as well. Determination coefficients of the model indicate its conformity with the data variation $\left(R^{2}=0.883, R^{2}\right.$ adj $\left.=0.881\right)$.

Cchanges in $\mathrm{Cr}(\mathrm{VI})$ concentration when using agar-immobilized Desulfomicrobium sp. CrR3 cells taking into consideration the factors of time, initial chromium content and concentration of cells conform with the interpretation of the visualization presented in Fig. 5.

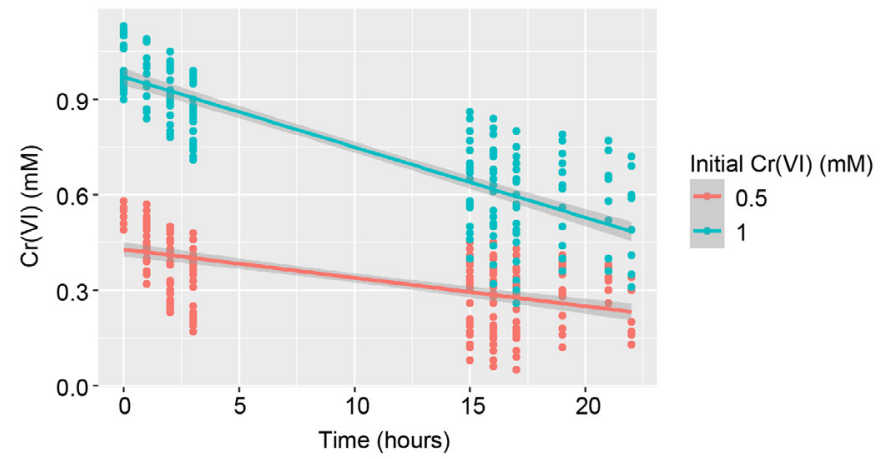

Fig. 5. Changes in $\mathrm{Cr}(\mathrm{VI})$ concentration by the agar-immobilized Desulfomicrobium sp. CrR3 cells taking into consideration the factors of time, initial chromium content and concentration of cells

Рис. 5. Зміни концентрації $\mathrm{Cr}(\mathrm{VI})$ іммобілізованими в агар Desulfomicrobium sp. CrR3 з урахуванням чинників часу, початкового вмісту хрому і концентрації клітин

Thus, the regression analysis of the influence of various factors on the of model solution purification from $\mathrm{Cr}(\mathrm{VI})$ by the agar-immobilized Desulfomicrobium sp. $\mathrm{CrR} 3$ cells showed a significant dependence of the changes in the parameter under study on time, initial content of hexavalent chromium and concentration of cells.

\section{CONCLUSIONS}

Immobilization of Desulfomicrobium sp. CrR3 cells is a promising way of water purification from hexavalent chromium compounds, which can be used to develop technologies for bioremediation of the environment from these pollutants. Effectiveness and duration of the process of water purification from $\mathrm{Cr}(\mathrm{VI})$ by the immobilized Desulfomic-

ISSN 1996-4536 (print) • ISSN 2311-0783 (on-line) • Біологічні Студії / Studia Biologica • 2020 • Том 14/№2 • C. 17-26 
robium sp. CrR3 bacteria depend on the initial hexavalent chromium content and the concentration of cells.

\section{COMPLIANCE WITH ETHICAL STANDARDS}

Conflict of Interest: The authors declare that the research was conducted in the absence of any commercial or financial relationships that could be construed as a potential conflict of interest.

Animal Rights: This article does not contain any studies with animal subjects performed by the any of the authors.

1. Bayat Z., Hassanshahian M., Cappello S. Immobilization of microbes for bioremediation of crude oil polluted environments: a mini review. Open Microbiol J, 2015; 9: 48-54.

[DOI: https://doi.org/10.2174/1874285801509010048; PMid: 26668662; Google Scholar]

2. Cai Y., Yang S., Chen D. Novel strategy to immobilize bacteria on polymer particles for efficient adsorption and biodegradation of soluble organics. Nanoscale, 2017; 9(32): 11530-11536.

[DOI: https://doi.org/10.1039/C7NR02610B; PMid: 28767111; Google Scholar]

3. Dzionek A., Wojcieszyńska D., Guzik U. Natural carriers in bioremediation: a review. Electronic Journal of Biotechnology, 2016; 19(5): 28-36.

[DOI: http://dx.doi.org/10.1016/j.ejbt.2016.07.003; Google Scholar]

4. Honchar T.M., Ksheminska H.P., Patsay I.O., Huta O.M., Gonchar M.V. Assay of chromium (III) in microbial cultures using chromazurol $S$ and surfactants for monitoring chromate remediation processes. Biotechnology, 2008; 1(4): 85-94. (In Ukrainian)

5. Klemps R., Cypionka H., Widdel F., Pfennig N. Growth with hydrogen, and further physiological characteristics of Desulfotomaculum species. Arch. Microbiol, 1985; 143(2): 203-208. [DOI: https://doi.org/10.1007/BF00411048; Google Scholar]

6. Marchart $H$. Uber die Reaktion von Chrom mit Diphenylcarbazid und Diphenylcarbazon. AnaIytica Chimica Acta, 1964; 196(30): 11-17.

[DOI: https://doi.org/10.1016/S0003-2670(00)88678-X; Google Scholar]

7. Peretyatko T.B., Halushka A.A., Gudz S.P. Usage of metals as the terminal electron acceptors by the sulfate-reducing bacteria. Biol. Stud., 2009; 3(3): 141-158. (In Ukrainian)

[DOI: http://doi.org/10.30970/sbi.0303.048; Google Scholar]

8. Postgate J.R. The sulfate-reducing bacteria. 2nd ed. Cambridge: Cambridge Univ. Press, 1984. 199 p.

9. R: A language and environment for statistical computing. $R$ Foundation for Statistical Computing, Vienna, Austria. R Core Team, 2020. URL https://www.R-project.org

10. Rozanova E.P., Nazina T.N. Sulfate-reducing bacteria (systematics and metabolism). Progress of microbiology, 1989; 23: 191-226. (In Russian)

11. Sholiak K.V., Peretyatko T.B., Gudz S.P. Sulphate-reducing bacteria resistant to increased levels of hexavalent chromium. Microbiology \& Biotechnology, 2013; 2: 66-76. (In Ukrainian) [DOI: https://doi.org/10.18524/2307-4663.2013.2(22).48922; Google Scholar]

12. Sholiak K.V., Peretyatko T.B., Gudz S.P. Electron acceptors for sulphate-reducing bacteria Desulfomicrobium sp. in the process of oxidation of organic compounds. Biol. Stud., 2013; 7(2): 57-64. (In Ukrainian)

[DOI: http://doi.org/10.30970/sbi.0702.562; Google Scholar]

13. Sholiak K., Hnatush S., Peretyatko T., Gudz S. Chromate- and sulfate-ions reduction by sulphate-reducing bacteria Desulfomicrobium sp. CrR3 under the influence of various organic compounds - environmental pollutants. Visnyk of Lviv University. Biological series, 2014; 65: 266-272. (In Ukrainian)

14. Shved O.M., Vydrynska O.K., Chervetsova V.H. Hubrii Z.V., Novikov V.P. New approaches to the biological purification of Lviv wastewaters. Visnyk of National University "Lviv Polytechnics", 2012; 726: 145-152. (In Ukrainian)

15. Tebo B.M., Obraztsova A.Y. Sulfate-reducing bacterium grows with $\mathrm{Cr}(\mathrm{VI}), \mathrm{U}(\mathrm{IV}), \mathrm{Mn}(\mathrm{IV})$ and $\mathrm{Fe}(\mathrm{III})$ as electron acceptors. FEMS Microbiology Letters, 1998; 162: 193-198.

[DOI: https://doi.org/10.1111/j.1574-6968.1998.tb12998.x; Google Scholar] 
16. Tkachenko T.L., Semenova O.I., Bublienko N.O. Immobilization of microorganisms of the active sludge as an effective method of intensification of the process of sewage purification of milk processing enterprises. Nutritional and manufacturing industry, 2009; 4-5: 20-22. (In Ukrainian)

17. Żur J., Wojcieszynska D., Guzik U. Metabolic responses of bacterial cells to immobilization. Molecules, 2016; 21(7): 958.

[DOI: https://doi.org/10.3390/molecules21070958; PMid: 27455220; Google Scholar]

\section{ВІДНОВЛЕННЯ СПОЛУК Сr(VI) ІММОБІЛІЗОВАНИМИ КЛІТИНАМИ СУЛЬФАТВІДНОВЛЮВАЛЬНИХ БАКТЕРІЙ DESULFOMICROBIUM SP. CrR3}

\section{Т. Б. Перетятко ${ }^{1 *}$, К. В. Шоляк², А. А. Галушка', І. М. Стахера ${ }^{3}$ Г. В. Цегелик \\ 1 Львівський національний університет імені Івана Франка вул. Грушевського, 4, Львів 79005, Україна \\ 2 зОШ I-III ступенів с. Дубриничі Закарпатської області вул. Центральна, 73, с. Дубриничі 89210, Україна \\ ${ }^{3}$ ВНКЗ ЛОР “Львівська медична академія імені Андрея Крупинського" вул. П. Дорошенка, 70, Львів 79000, Україна \\ *Кореспондуючий автор: e-mail: taras.peretyatko@Inu.edu.ua}

Іммобілізація мікроорганізмів $€$ ефрективним методом інтенсифікації процесу очищення стічних вод від хроматовмісних сполук. У цій статті розроблено спосіб іммобілізації в агар сульфатвідновлювальних бактерій з метою з'ясування ефективності очищення води від токсичних сполук $\mathrm{Cr}(\mathrm{VI})$. Досліджено залежність впливу різних чинників на відновлення сполук $\mathrm{Cr}(\mathrm{VI})$ іммобілізованими клітинами сульфатвідновлювальних бактерій Desulfomicrobium sp. CrR3. Іммобілізовані в агар та неіммобілізовані клітини Desulfomicrobium sp. CrR3 практично повністю відновили $\mathrm{Cr}(\mathrm{VI})$ за вихідної концентрації 1 мМ. Іммобілізовані клітини відновили понад 90 \% Cr(VI) протягом чотирьох діб, а неіммобілізовані - протягом шести діб. Зі зменшенням концентрації Cr(VI) зростав вміст Cr(III). Встановлено можливість кількаразового використання іммобілізованих в агар клітин Desulfomicrobium sp. CrR3 для очищення модельного розчину від $\mathrm{Cr}(\mathrm{VI})$ у концентрації 0,5 та 1 мМ протягом 60 год. За триразового використання іммобілізованих клітин ефективність відновлення $\mathrm{Cr}(\mathrm{VI})$ становить 68 \% за вихідної їхньої концентрації 0,5 мМ та $50 \%$ - за 1 мМ; за концентрації клітин 3 г/л - 87 та 77 \%; 5 г/л - 94 та 92 \% і за концетрації клітин 8 г/л - 98 і 96 \%, відповідно. Унаслідок проведеного регресійного аналізу щодо впливу різних чинників на очищення модельного розчину від $\mathrm{Cr}(\mathrm{VI})$ іммобілізованими в агар клітинами Desulfomicrobium sp. CrR3, встановлено достовірну залежність зміни досліджуваного параметра від часу, початкового вмісту $\mathrm{Cr}(\mathrm{VI})$ та концентрації клітин. Розраховано показники детермінації та виведено рівняння залежності зміни концентрації $\mathrm{Cr}(\mathrm{VI})$ за одиницю часу від двох-трьох проаналізованих чинників. Іммобілізація в агар клітин Desulfomicrobium sp. CrR3 $€$ перспективним способом очищення води від сполук $\mathrm{Cr}(\mathrm{VI})$. Ефективність і тривалість процесу очищення водного середовища від $\mathrm{Cr}(\mathrm{VI})$ іммобілізованими бактеріями Desulfomicrobium sp. CrR3 залежать від початкового вмісту $\mathrm{Cr}(\mathrm{VI})$ та концентрації клітин.

Кючові слова: $\mathrm{Cr}(\mathrm{VI})$, очищення, іммобілізовані клітини, сульфатвідновлювальні бактерії, регресійний аналіз

Received / Одержано 04 March 2020
Accepted / Прийнято 22 May 2020
Published / Опубліковано 22 June 2020

ISSN 1996-4536 (print) • ISSN 2311-0783 (on-line) • Біологічні Студії / Studia Biologica • 2020 • Том 14/№2 • C. 17-26 